International Journal of Biology, Pharmacy and Allied Sciences (IJBPAS)

'A Bridge Betusen Caboratory and QRader'

WWW.iibpas.com

\title{
NYMPHAEA ALBA: A DETAILED STUDY
}

\section{AGNIHOTRI $\mathbf{S}^{1^{*}}$, SINGH $G^{2}$, NARWAL $S^{2}$ AND BALRAM ${ }^{3}$}

1: Chandigarh College of Pharmacy, Chandigarh Group of Colleges, Landran, Punjab India

2: I. K. Gujral Punjab Technical University, Kapurthala, 144603 Punjab India

3: Institute of Pharmaceutical Sciences Kurukshetra University Kurukshetra, Haryana India

*Corresponding Author: E-Mail: asupriya149@gmail.com

Received 25 ${ }^{\text {th }}$ Jan. 2020; Revised $27^{\text {th }}$ Feb. 2020; Accepted $3^{\text {rd }}$ April 2020; Available online $1^{\text {st }}$ Sept. 2020

https://doi.org/10.31032/IJBPAS/2020/9.9.5194

\begin{abstract}
Nymphaea alba commonly known as white water Lily, is a hydrophyte having enormous medicinal properties. It is famous for its alluring white flowers. It is distributed across the globe in ponds, lakes and marshy areas. Its different parts have been used traditionally, to treat variety of ailment, in various medicinal systems including Arabic, Unani, Ayurvedic and Chinese medicines. By using contemporary pharmacological methods, traditional use of Nymphaea alba has been substantiated for curing different diseases. In-depth research provides an estimate of the pharmacological effects of different extracts or isolated compounds of Nymphaea alba. By using in vivo or in vitro methods is established that Nymphaea alba has therapeutic potential to treat diarrhea, hepatotoxicity, inflammation, anxiety and depression and convulsions etc. In addition, Nymphaea alba extracts also found to have a certain degree of anti-cancer and anti-bacterial activity. This review is an attempt to compile Nymphaea alba's current ethanomedicinal, morphological, phytochemical and pharmacological data.
\end{abstract}

\section{Keywords: Ethnobotanical, Flavonoids, Nymphaea alba, Quercetin, White water Lily} \section{INTRODUCTION}

Nymphaea alba belongs to Nymphaeaceae family which comprises of the several valuable medicinal plants with a wide range of pharmacological and biological actions along with established to have important phytochemical components [1]. The genus Nymphaea comprises of about forty fifty species [2], out of which five species are 
present in India, and some are grown as ornamental plant [3]. Nymphaea alba frequently referred to as "European White Water Lily or Nenuphar. It is a perennial hydrophyte having a black, Sturdy, almost horizontal, scarcely branched rhizome submerged in the mud [4]. It preferably grows in neutral to alkaline waters in puddle, stagnant or slightly moving lakes and marshy areas [5]. It grows at depth of about $.5-3 \mathrm{~m}$., in water over mud, silt or Peat [4]. It is spread extensively throughout Europe, north Africa, north \& central Asia, southwest Asia, Finland, India, China, Russia, Turkey and Poland [4, 6-8]. Nymphaea alba was thought to be a plant of lowland waters, but is also occurs at higher altitudes in Kashmir (India) at 1500 m., in Angle Tarn (England) at $456 \mathrm{~m}$., inIsla (Scotland) at $426 \mathrm{~m}$. and in Ireland at $335 \mathrm{~m}[4,9]$. It occurs in temperate and tropical regions [10]. In India it is widely distributed in the lakes and ponds of Bengal, Orissa to Kashmir [3, 11].

\section{SYNONYMS [12]}

Eng: European White Water Lily

Latin: Nenuphar

Arabic: Nilufar

Beng: Kumuda, Shandh shaluka

Guj: Piyanu

Hindi: Kanval, Kokka

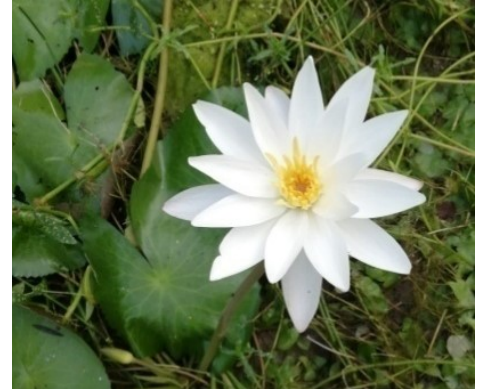

Figure 1: Nymphaea alba

\section{DESCRIPTION}

Nymphaea albavaries in size considerably, it can spread upto 20 feets. Flower: Nymphaea alba has big white flowers consisting of 4 to 5 sepals, Two to three rows $12-33$ of petals arranged in 2 to 3 or more rows [13]. Sepals are linear or ovate, oblong and nerves are reticulate Petals are outer linear-oblong equaling the sepals [13]. Anterior sepals represent bract and lateral sepals' bracteoles [4]. It has abundant anthers in the center which are of yellow in color [14]. During anthesis flowers closes at night and opens during day [15]. Leaves are oval, cordate, entire or sub-orbiculate can have a diameter of up to thirty centimeters and covers up 150 centimeters of area per plant $[13,16]$.Color of leavesvaries that is dark green at top and reddish brown below[17]. It has a smooth and slightly striated cuticle [18]. The fruits are fleshy spongy and capsular and ripe in water, it contains up to 1700 seeds per fruit, 2-5 $\mathrm{mm}$ long, punctuate, buried in pulp , dark olive green in color having smooth surface [4, 13]. Nymphaea alba has perennial rhizomes which helps it to survive and grow again [19]. 


\section{ETHNOBOTANICAL USES}

Nymphaea alba has a history of ethnobotanical applicationsin different cultures [10]. Almost each partof this plant has been usedto treat variety of illness [20]. Its root andrhizome were used to treat or relief GIT, reproductive and lungs disorder [20]. Ariel parts specially leaves as well as roots of Nymphaea alba were utilizedas poultice to boils, inflamed skin and scrofulous ulcers. The pulp of its rhizome shows rubefacient effect when applied externally [21]. Seeds of Nymphaea alba used for its Diaphoretic action [22]. A decoction prepared from its root was used in irritable bowel syndrome for management of diarrhea. It was also utilized for the treatment of bronchial catarrh \& kidney pain and for sore throat [6]. Moreover, this plant has been used from older times for various actions including aphrodisiac, anti-inflammatory action, anodyne, astringent, cardiotonic, demulcent, antioxidant, sedative action [19]. Apart from traditional usage of Nymphaea alba for its medicinal credence, it is also consumed as a food supplement for its nutritional importance like its soft part of leaves, stalks bearing flowers are part of diet of several ethnic groups. In addition its Starch rich rhizomes are consumed in raw form or boiled at several places. A combination of black pepper and its pistils are used for internal and external purposes. Flour of its seeds is mixed with wheat and barley flour [23]. During dearth, its rhizomes were boiled and parched seeds were consumed as meal in China and East Indies its dried seed flour with wheat flour was used in making mixed breads. In addition its rhizomes are used for tanning purposes [24].

\section{PHYTOCHEMICAL STUDIES}

Nymphaea alba is reported to have variety of chemical constituents including alkaloids, tannins, flavonoids, Phenolic content and glycosides [25-27]. Its flowers were established to have isolated aglycons including: quercetin, isokaempferide, kaempferol, and apigenin along withvarious glycosides moieties including quercetion 4'- $\beta$-xyloside, 3-methylquercetin $3 '-\beta$-xyloside as well as combination of quercetin 3-galactoside and 3-glucoside [26]. It was also obtained to have variety of phenolic acids like Gallic Acid, Ellagic acid, methyl and ethyl esters of gallic acid, also found to have traces of Ferulic, vanillic, $\mathrm{p}$-cumaric and p-hydroxy benzoic acid [26, 27]. Its alcoholic extract of flowers was reported to have cardiac glycoside Nymphalin [23]. It was estimated from chemical composition of Nymphaea albathat it has abundance of proteins, essential inorganic compounds which provides energy and has less fiber [28].

In another research, presence of polyphenols and flavonoids is confimed, a 
total of 27 compounds were identified, having major proportion of rutin and pcoumaric acid along with caffeic acid, catechin, epicatechin, naringin, naringenin, vanillic acid, corilagin, tannic acid, gallic acid, ferulic acid, ellagic acid, quinic acid, kaempferol, castalin, orientin, apigenin, luteolin, brevifolin, ellagic acid rhamnosyl, quercetin, HHDP-hexoside [29]. It is has traces of some inorganic substances including copper, sulphate, chloride [13] Nymphaea alba rhizomes were also proved to have five main phenolicsincluding, gallic acid and its methyl and ethyl ester,ellagic acid and pentagalloyl glucose [30].<smiles>COc1c(-c2ccc(O)cc2)oc2cc(O)cc(O)c2c1=O</smiles>

Isokaempferide<smiles>O=c1cc(-c2ccc(O)cc2)oc2cc(O)cc(O)c12</smiles>

apigenin<smiles>O=C1Oc2c(O)c(O)cc3c2c(=O)oc2c(O)c(O)cc1c23</smiles>

Ellagic acid<smiles>O=c1c(O)c(-c2ccc(O)c(O)c2)oc2cc(O)cc(O)c12</smiles>

Quercetin<smiles>O=C1C(OC2OC(CO)[C@@H](O)C(O)[C@H]2O)C(c2ccc(O)c(O)c2)OC2=CC(O)CC(O)C12</smiles>

quercetin 3-galactoside<smiles>O=C(O)/C=C/c1ccc(O)c(O)c1</smiles>

Ferulic acid<smiles>O=c1c(O)c(-c2ccc(O)cc2)oc2cc(O)cc(O)c12</smiles>

Kaempferol<smiles>O=C(O)c1cc(O)c(O)c(O)c1</smiles>

Gallic Acid<smiles>COc1cc(C(=O)O)ccc1O</smiles>

vanillic acid 


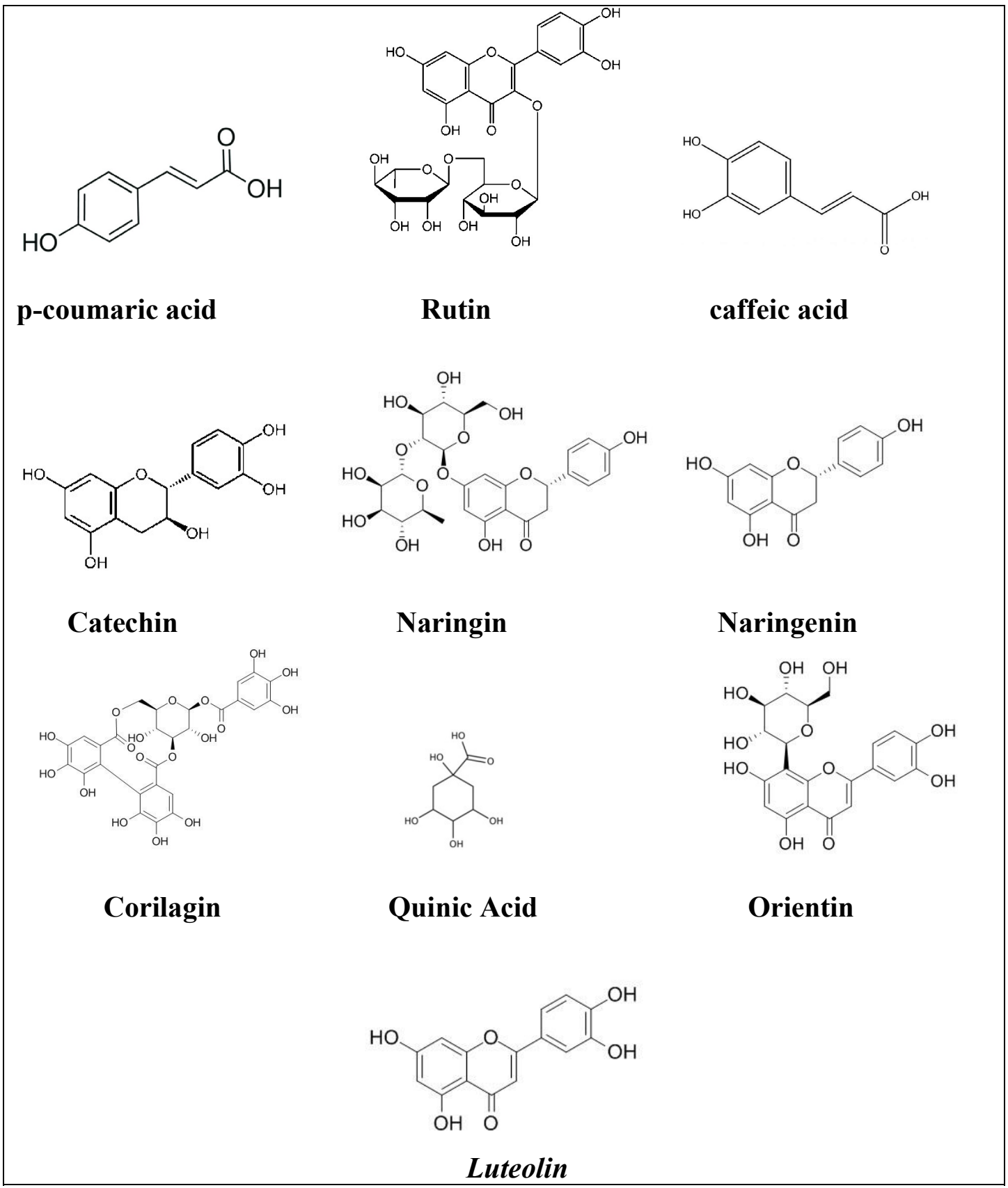

Figrue 2: The structures of phytoconstituents of Nymphaea alba

PHARMACOLOGICAL ACTIVITIES

Anti - Inflammatory activity:

Ethanol extract of rhizome of Nymphaea alba was used to evaluate its analgesic activity. Male mice (20-30 g) were used in acetic acid-induced writhing in mice and Formalin-induced nociception.200mg/kg, $400 \mathrm{mg} / \mathrm{kg}$ and $600 \mathrm{mg} / \mathrm{kg}$ of extract was administered orally along with $100 \mathrm{mg} / \mathrm{kg}$ of standard drug paracetamol, the percent inhibitions assessed is $57.55 \%, 64.52 \%$, $76.55 \%$ and $51.18 \%$, respectively with comparison to control values. Similarly, same doses of extract showed significant results in the formalin-induced pain. Highest dose that is $600 \mathrm{mg} / \mathrm{kg}$ of the extract, showed better results in comparison 
to standard drug, in formalin-induced pain [31].

Anti-inflammatory activity of Nymphaea alba flowers was evaluated using ethanol extract. Two anti-inflammatory models were employed to figure out acute and chronic anti-inflammatory activity. For acute inflammation, acetic acid induced vascular permeability model was used on the other hand for chronic cotton-pellet induced granuloma as taken. Dose of $100 \mathrm{mg} / \mathrm{kg}$ and $200 \mathrm{mg} / \mathrm{kg}$ of ethanol extract was administered orally in mice. The doses 100 and $200 \mathrm{mg} / \mathrm{kg}$ exhibited inhibition of 10.1 percent and 41.5 percent respectively in granuloma formation, however standard diclofenac reflected 57.30 percent inhibition in contrast to control. Whilst, extract exhibited $20.35 \%$ and $33.54 \%$ inhibition in acetic acid-induced vascular permeability model, where diclofenac sodium showed 43.13 in comparison to control [16].

In another study, to substantiate anti inflammatory activity of hydroalcohol extract of Nymphaea alba flowers, HRBC membrane stabilization method was taken into account. Different concentrations including $200 \mu \mathrm{g} / \mathrm{ml}$ and $500 \mu \mathrm{g} / \mathrm{ml}$ represented remarkable stabilization of the HRBC membrane. Concentration $500 \mu \mathrm{g} / \mathrm{ml}$ of extract exhibited higher percentage protection [1].

Anti-hepatitis $\mathrm{C}$ activity:
Anti- hepatitis $\mathrm{C}$ activity is done using methanol extract and acetone extracts of Nymphaea alba with its purified fractions. Study was carried out by utilizing transfection model on Huh-7 cell line. MDBK cell line was used to analyze Synergistic effects of purified fractions with interferon in transfection model. By using in-vitro transfection model, effect of two isolated acetone extract fractions ' $\mathrm{N} 1$ ' \& 'N8'was observed on hepatitis $\mathrm{C}$ virus replication by studying viral gene expression. In addition, taking NS3 protease as an active target, interaction of NS3 protease with fourteen constituents of Nymphaea alba was carried out using Molecular Operating Environment (MOE) software, boceprevir was taken as standard NS3 protease inhibitor. Reported 84 and 94 percent fall hepatitis C virus NS3 gene expression. Further, combination of boceprevir with isolated fraction showed synergistic effects and increased inhibitory effect of hepatitis $\mathrm{C}$ virus replication [32].

\section{Anti-diarrheal activity:}

Castor oil induced diarrhoea model using Wistar rats were employed to find out antidiarrheal properties of Nymphaea alba. Ethanol extract was prepared from Rhizomes and roots. 100 and $200 \mathrm{mg} / \mathrm{kg}$ dose of Nymphaea alba was administered through oral route that induced reduction in defecation rate, $5 \mathrm{mg} / \mathrm{kg}$ diphenoxylate was taken as standard. In comparison to 
standard,100 and $200 \mathrm{mg} / \mathrm{kg}$ ethanol extract expressed comparable percentage inhibition of $92.6 \%$ and $93.8 \%$ respectively [2].

\section{Hepatoprotective activity:}

Nymphaea alba flowers were evaluated for hepatoprotective activity usingCCl${ }_{4}$ and acetaminophen induced hepatotoxicity methods. Wet liver mass and wet liver quantities are significantly inhibited by two doses of ethanol flowers extract that is $200 \mathrm{mg} / \mathrm{kg} \quad \& \quad 400 \mathrm{mg} / \mathrm{kg}$. Results of biochemical estimation reflected remarkable depletion in SGOT, SGPT, ALP, Bilirubin and cholesterol level in comparison to control group. Dose 400 $\mathrm{mg} / \mathrm{kg}$ showed the highest inhibition in both models [33].

In another study Nymphaea alba leaf extract was involved for analyzing its hepatoprotective action. Carbon tetra chloride-induced hepatotoxicity model was used to evaluate efficacy of Nymphaea alba extract, on eight-week-old male Wistar albino rats, silymarin was taken as standard. Two doses $100 \mathrm{mg} / \mathrm{kg}$ and 200 $\mathrm{mg} / \mathrm{kg}$ of aqueous ethanolic extract significantly enhanced liver functions oxidative stress parameter along with TNF$\alpha$. Results validated that aqueous ethanolic extract of Nymphaea albahas hepatoprotective activity concordant to standard drug silymarin [34].

Isoniazid Induced hepatoxicity:
Hepatotoxicity was induced by isoniazid $(50 \mathrm{mg} / \mathrm{kg}$ ) in rats. In the study, 50mg / $\mathrm{kg}$ of Silymarin was taken as standard drug. Dose of 200 and $400 \mathrm{mg} / \mathrm{kg}$ of Nymphaea alba flowers ethanol extract was administered along with Silymarin for 31 days. Isoniazid was administered from 4th to 31 st day of the study in standard and test groups. All drugs have been given orally. Both doses considerably reduced rise of different markers like liver marker enzymes SGOT, SGPT along with serum bilirubin, catalase, malondialdehyde, glutathione in rats hence exhibits protective actionin isoniazid induced hepatotoxicity in rats. In addition avoided the elevation of liver MDA content and increased GSH content resulting from rat liver intoxication with Isoniazid challenge [35].

\section{Antibacterial activity:}

The current research was conducted to assess the antibacterial activity of Nymphaea alba. Complete plant was used to make extracts, using ethanol and acetone. Three strains of bacteria were incorporated in the current study that is E. coli, Vibrio sp. and S. aureus. Both Acetone and ethanolic extract showed greater inhibition areas of $26.2 \mathrm{~mm}$ and $18.8 \mathrm{~mm}$ respectively against Vibrio $s p$. Minimum inhibition concentration values of acetone extract found to be between 20.0 $\mathrm{mg} / \mathrm{mL}$ to $160.0 \mathrm{mg} / \mathrm{mL}$ in comparison to ethanolic extract which ranges from 10.0 
$\mathrm{mg} / \mathrm{mL}$ to $80.0 \mathrm{mg} / \mathrm{mL}$. Nymphaea alba acetone extract exhibits greater antibacterial activity against Vibrio $s p$. [36].

In other studies antibacterial activity flowers of Nymphaea alba was carried out against four different strains of bacteria that were Bacillus subtilis, Staphylococcus aureus, Klebstella pneumonia and Escherichia coli. For the screening, hydroalcohol extract flowers of nymphaea abla were used. Muller Hinton agar media was prepared thenthe cultures of respective bacteria grown in nutrient broth were swabbed on plates. After that $25 \mu$ leach extract was taken to suffuse sterile discs of 6 mmdiameter.Inference of the whole study signified that Nymphaea alba has high activity for staphylococcus aureus, Escherichia coli and Bacillus subtilis. Plant extract showed concordant results against various bacteria, gentamycin was taken as standard [37]. Nymphaea alba was also reported to have activity against Pseudomonas aeruginosa [38]. Ethanol and methanol extracts of Nymphaea alba exhibited potent antibacterial activity in a research, on multiple plants taking 10 different bacterial strains using disc diffusion technique [39].

Ethanol extracts of Nymphaea alba was also evaluated to trace out its antibacterial potential against Listeria monocytogenes infection using mice. Animals were exposed to $100 \mu 1$ and $200 \mu \mathrm{l}$ of the pathogen. Listeria monocytogenes infection causes changes in behavior, sunken eyes, eye secretions, hyperactivity, circumflex backbone, sedation, and mortality as signs of infection. Count of lymphocyte along with neutrophils elevates due to the infection, yet their levels found to be in a normal range in the infection pretreated with Nymphaea alba as it significantly inhibits infection, It also cause enhancement of the platelets production and stablises WBC's count [40].

\section{Anticarcinogenic effect:}

Nymphaea alba methanol extract was researched to investigate the prophylactic action against oxidative stress on kidneys, renal carcinogenesis and hyperproliferative reaction on wistar rats. Two different protocols were used, first one was designed to analyze the preventive effect of Nymphaea albaon renal oxidative stress induced by ferric nitrilotriacetate and ornithine decarboxylase induction. In other the anticancer effect of Nymphaea alba was evaluated against Diethylnitrosamine, as well as ferric nitrilotriacetate induced renal tumor. $100 \mathrm{mg} / \mathrm{kg}$ and $200 \mathrm{mg} / \mathrm{kg}$ oral doses of Nymphaea alba exhibited depletion of different parameters taken in the study along with reduction in incidence of tumor [20].

In another research, anticancer activity of Nymphaea alba was determined by using 
Sulpharhodamine-B assay, four cancer cell lines were utilized including THP-1 (leukaemia), PC-3 (Prostrate), A-549 (lung) and HCT-15 (Colon). 100 $\mu \mathrm{g} / \mathrm{ml}$ and $50 \mu \mathrm{g} / \mathrm{ml}$ of extract were screened for 48 hours, using 96-well plate reader; readings were taken at $540 \mathrm{~nm}$. Exhibited inhibition of growth, during 48 hour incubation. Chloroform and petroleum ether extract exhibited consequential effects [3].

Cytotoxic activity of several isolated constituents from Nymphaea albawas reported including Methyl gallate that exhibited best results against HepG2- cell line with $\mathrm{IC} 50=9.61 \mu \mathrm{g} / \mathrm{ml}$, whilst ethyl gallate along with pentagalloyl glucose showed IC50 - $41.9 \mu \mathrm{g} / \mathrm{ml}$ and $41.2 \mu \mathrm{g} / \mathrm{ml}$, respectively I comparison to standard Doxorubicin $0.56 \mu \mathrm{g} / \mathrm{ml}$ [30]. In another study ethanol extract of Nymphaea alba was analysed for antitumor activity using potato-disc tumor assay induced with Agrobacterium tumefaciens, and results reflected that it can significantly inhibit tumor [39].

Efficacy of methanol extract of Nymphaea alba in renal oxidative stress induced by potassium bromate as well as ornithine decarboxylase induction was evaluated. $125 \mathrm{mg} / \mathrm{kg}$ of $\mathrm{KBrO}_{3}$ was administered intra-peritoneal in unit dose to induce renal oxidative stress. Three groups of animals were pretreated with $100 \mathrm{mg} / \mathrm{kg}$ and 200 $\mathrm{mg} / \mathrm{kg}$ prior to treatment with $\mathrm{KBrO} 3$.
Animals that were treated with extract reduced renal glutathione, antioxidant enzymes along with phase-II metabolising enzymes and enhanced xanthine oxidase, glutamyl transpeptidase, lipid peroxidation and hydrogen peroxide. This study signifies that Nymphaea alba activity as chemo preventive agent against $\mathrm{KBrO} 3$-mediated renal oxidative stress and exhibited depletion of tumor occurance in Wistar rats [20].

\section{Antiurolithiatic activity:}

Antiurolithiatic potential of Nymphaea alba was evaluated using ethanol extract of dried leaves. Dose of Nymphaea albawasgiven orally. To induce urolithiasis zinc disc was inserted in the urinary bladder followed by supplementing drinking water having $1 \%$ ethylene glycol.Weight reduction of the stones was taken as criteria for estimating the preventive or curative regimen. Results determine that Nymphaea alba oral administration leads to concordant decrease of bladder stones weight in comparison to the control [19].

\section{Uterotonic properties:}

Uterotonic properties rhizomes of Nymphaea alba was investigated using ethanol extract of rhizomes of Nymphaea alba. Virgin female wistar rats (120-130 g) were incorporated into studies, $1 \mathrm{mg} / \mathrm{kg}$ of stilboesterol was administered subcutaneously for estrogenized uterus preparation. Nymphaea alba ethanol extract 
exhibited uterine stimulant like effect in the presence of salbutamol and atropine from. Dose dependent elevation uterine contraction force was observed that is similar to Oxytocin. Oxytocin potentiated the activity of extract whilst atropine or salbutamol shows inhibitory effects on the activity of the extract represented that extract has uterotonic properties [11].

\section{Anxiolytic activity:}

Ethanol extract of Nymphaea alba plant was explored to trace out its anxiolytic activity using male albino mice. To assess the anxiolytic activity various models were incorporated during investigation: the elevated plus maze test, light and dark test and open field test. In addition to access aggressive behavior and motor coordination foot shock induced aggression test along with rota rod test were involved in the research. Two doses 100 and $200 \mathrm{mg} / \mathrm{kg}$ were administered orally and $1 \mathrm{mg} / \mathrm{kg}$ Diazepam was taken as a standard. Both doses of ethanol extract of Nymphaea alba remarkably enhanced the duration of time spend, percentage and count of entries in open arm and elevated plus maze test. There is remarkable enhancement in time spent, crossing count and deplition in the interval of movement in light box. In addition, extract enhances count of rearings along with assisted rearings and count of crossed squares in open field test. In FSIAT, Nymphaea alba extract diminished anxiety by reducing attacks showing aggression by animal [16].

\section{Antidepressant activity:}

Antidepressant activity of Nymphaea alba flowers was investigated in mice using Tail suspension test along with forced swim test. Two doses that are $100 \mathrm{mg} / \mathrm{kg}$ and $200 \mathrm{mg} / \mathrm{kg}$ of ethanolic extract of Nymphaea alba flowers were taken and a comparative analysis was done taking Imipramine $10 \mathrm{mg} / \mathrm{kg}$ as standard. And it was observed that dose $100 \mathrm{mg} / \mathrm{kg}$ showed a more depletion in the time immobility in comparison to its higher dose $(200 \mathrm{mg} / \mathrm{kg})$ as well as more than standard drug [41].

CNS depressant activity:

Ethanol extract of Nymphaea alba rhizomes was evaluated for it CNS depressant activity. Different doses were administered to mice including $75 \mathrm{mg} / \mathrm{kg}$, $150 \mathrm{mg} / \mathrm{kg}$ and $300 \mathrm{mg} / \mathrm{kg}$ to study behavioral effects. Diazepam induced sleep test, holeboard test, beam walking, staircase test, open field test and elevated plus maze were incorporated for evaluation. Results reflected that Nymphaea albarhizome exhibits sedative properties and exhibits concordant results in comparison to the standard drug [10].

\section{Anticonvulsant activity:}

Anticonvulsant properties of Nymphaea alba flowers ethanol extract in rats was evaluated.MES induced seizures using Electroconvulsiometer and Pentylene 
tetrazole (PTZ 70mg/kg i.p) induced seizure model were used to evaluate Anticonvulsant activity. For both of the methods, Phenytoin sodium and sodium valproate were used as standard drugs respectively. Two different doses were selected for ethanol extract of Nymphaea alba $(200 \mathrm{mg} / \mathrm{kg}$ and $100 \mathrm{mg} / \mathrm{kg}$ of body weight) and given orally 1 hour before induction of seizures. Both significantly prevented tonic hind limb extension phase and also lower down the time interval of seizures in MES models. PTZ induced model revealed that extract showed little protection compared to control however, was insignificant statistically [42].

\section{Antihyperlipidemic activity:}

Nymphaea alba was studied for antihyperlipidemic activity. Methanol extract of Nymphaea alba leaves was tested against triton induced hyperlipidemia in rats. Dose of $100 \mathrm{mg} \& 200 \mathrm{mg} / \mathrm{kg}$ (p.o) methanolic extract of Nymphaea alba was administeredto hyperlipidemic rats which is induced by triton $(400 \mathrm{mg} / \mathrm{kg})$. Fenofibrate was taken as standard drug for reference. Biochemical Analysis reveals that Nymphaea alba shows a concordant cholesterol level depletion along with phospholipids, LDL, VLDL, triglyceride and significant rise in the serum HDL level at 100 and $200 \mathrm{mg} / \mathrm{kg}$. Total cholesterol serum level was reduced by $74.25 \%$ and
$32.76 \%$ reduction of LDL cholesterol level [43].

\section{Antioxidant activity:}

Antioxidant activity of two different extracts (aqueous and ethanol extracts) of flowers of Nymphaea alba were examined by several antioxidant screening methods involving free radical scavenging by $\mathrm{H}_{2} \mathrm{O}_{2}$, total antioxidant and nitric oxide (NO) scavenging activities. Significant results were obtained from the assays indicating that both the extract have potent antioxidant properties. In contrast to aqueous extract ethanol extract exhibited more significant results [44]. An another study reveals the antioxidant potentials of different extracts of Nymphaea alba flowers determines its antioxidant potentials using DPPH radical scavenging assay. The results showed that methanol, ethyl acetate and aqueous extract of Nymphaea alba has promising antioxidants capacities [3].

\section{MISCELLANEOUS:}

Nymphaea alba was reported to have potency of accumulating heavy metals like lead cadmium and manganese at varying concentrations and $\mathrm{pH}[\mathbf{4 5}, \mathbf{4 6}]$. Manganese showed highest deposition that is 3.743 $\mathrm{mg} / \mathrm{g}$ at $5 \mathrm{mg} / \mathrm{L}$ concentration and $\mathrm{pH} 6.5$, however cadmium showed minimum value that is $0.464 \mathrm{mg} / \mathrm{g}$ at $1 \mathrm{mg} / \mathrm{L}$ concentration and $\mathrm{pH} 5.5$ [45]. Its roots can also absorb mercury phenol as well as filter microorganisms hence it can be claimed 
that Nymphaea alba can be used as biological filter for eliminating heavy metals from industrial wastes $[45,47]$. Relationship between different concentrations of various elements like Barium, cobalt and copper has also been observed [48]. In another study absorption of Chromium by different parts of Nymphaea alba as well as its toxic effects over plant has been investigated 48. Effect of different factors including $\mathrm{pH}, \mathrm{Al}$ and $\mathrm{HCO}_{3}^{-}$were studied to trace out decomposition pattern as well as constitutions of leaves [49].

\section{CONCLUSION}

Natural products are attaining popularity worldwide, knowing their disease curing properties with rare side effects. Contemporary laboratory techniques exhibited their versatile role in

\section{REFERENCES}

[1] Karthikeyan R. Anti-Inflammatory Activity of Flowers of Nymphaea alba by HRBC Membrane Stabilization Method. Res Plant Biol. 2015; 5(4).

[2] Bose et al. In vivo evaluation of antidiarrheal activity of the rhizome of Nymphaea alba (Nymphaeaceae). OPEM. 2012; 12(2): 129-34.

[3] Nazir S, Qureshi M ,Chat O. Antitumor, Anti-oxidant and Anti-microbial potential of Nymphaea alba and Nymphaea mexicana flowers-a development of herbal medicines. There are varieties of synthetic molecules which are derivatives of isolated plant constituents and are used for their therapeutic values. Nymphaea alba has been used from older times traditionally for treating different ailments. Moreover its applications were proven by ethnomedicine systems that were developed by different ethnic groups. By using latest techniques of investigation Nymphaea alba has been explored for a number of different disorders and shown promising results that is a testimony for their traditional applications. It has been reported to have variety of potentials ranging from antioxidant properties to chemo preventive agent. Although different research has been done on Nymphaea alba, still there is huge scope to explore its hidden potentials.

comparative study. Adv. Biomed Pharma. 2015; 2: 196-204.

[4] Heslop-Harrison Y. Nymphaea L. J Ecol. 1955; 43(2): 719-34.

[5] Chiej R. Encyclopaedia of medicinal plants. MacDonald. Materia medica, Vegetable. 1984.

[6] Lakshmi T, Madhusudhanan N ,Rajendran R. Nymphaea alba Linn-An Overview. Res J Pharm Technol. 2013; 6(9): 974.

[7] Sumlu S, Atar H, Khawar K. Breaking seed dormancy of water lily (Nymphaea alba L.) under in vitro conditons. 
Biotechnol Biotechnol Equip. 2010; 24(1): 1582-6.

[8] Kłosowski S ,Tomaszewicz H. Habitat conditions of the Nymphaeetum candidae Miljan 1958 and NupharoNymphaeetum albae Tomaszewicz 1977 dominated by Nymphaea alba . ACTA SOC BOT POL. 1989; 58(4): 613-24.

[9] Conard H S. The waterlilies: a monograph of the genus Nymphaea. Pub. by the Carnegie Institution of Washington. 1905.

[10]Bose A, Ray S D ,Sahoo M. Central depressant activity of ethanol extract of Nymphaea alba rhizome in mice. OPEM. 2013; 13(2): 159-64.

[11]Bose A, Moumita S ,Sudhanshu S. Uterotonic properties of Nymphaea alba on isolated myometrium model. Int J Pharm Pharm Sci. 2014; 6: 490-3.

[12] Khare C P. Ayurvedic pharmacopoeial plant drugs: expanded therapeutics. Routledge. 2015.

[13] Afshan Khan A S, Anwar Jamal. Gule nilofer (Nymphaea alba) an influential drug in unani medicine: a review with immence therapeutic potential and phyto-pharmacological perspective. IntJ Adv I Res. 2019; 6(1(I)).

[14] Vitek E F G, Oganesian M, Tamanyan $\mathrm{K}$, Ter-Voskanyan H, Margaryan K, Tumanyan A. Nymphaea alba
(Nymphaeaceae) in Armenia. Rostaniha. 2013; 14(1): 43-7.

[15] Velde G V d. Developmental stages in the floral biology sl of Dutch Nymphaeaceae (Nymphaea alba L., Nymphaea candida Presl, Nuphar lutea (L.) Sm.). Acta botanica neerlandica. 1986; 35(2): 111-3.

[16] Jacob Jesurun, Jagadeesh S, Ganesan S, Eerike M. Anti inflammatory activity of ethanolic extract of Nymphaea alba flower in swiss albino mice. Int J Med Res Health Sci. 2013; 2(3): 474-8.

[17]Diksha Matta $H$ n, Gayathri Mahalingam. Phytopharmaceutical potentials of prosopis laevigata, symplocos cochinchinensis and Nymphaea alba: a review. Asian J Pharm Clin Res. 2017; 10(10): 63-8.

[18]Zini L M, Galati B G ,Ferrucci M S. Perianth organs in Nymphaeaceae: comparative study on epidermal and structural characters. Int J Plant Res. 2017; 130(6): 1047-60.

[19]Lakshmi T, Devaraj E. Antiurolithiatic activity of phytochemical extracts: A review. J Adv Pharm Educ Res. 2017; $7(3)$.

[20]Khan N, Sultana S. Inhibition of potassium bromate-induced renal oxidative stress and hyperproliferative response by Nymphaea alba in Wistar 
rats. J Enzyme Inhib Med Chem. 2005; 20(3): 275-83.

[21] SK B. Handbook of Indian medicinal plants. Jaipur, India: Pointer Pulishers.

[22] Evans W C. Trease and evans' pharmacognosy E-book. Elsevier Health Sciences. 2009.

[23] Selvakumari E, Shantha A, Kumar C S, Prabhu T P. Phytochemistry and Pharmacology of the Genus Nymphaea. J Acad Ind Res. 2016; 5(7): 98.

[24]DMA J. Medicinal plants used in Ceylon. National Science Council. 1982.

[25] Abirami A G N, Vazhayil Saipriya Ashwathi, Rajagopal Siddhuraju, Perumal. Influence of thermal treatments on polyphenolic contents and antioxidant properties of underutilized edible flowers of Nelumbo nucifera and Nymphaea alba. IJHSR. 2017; 7(10): 211-23.

[26] Jambor J ,Skrzypczak L. Phenolic arids from the flowers of Nymphaea alba L. Acta Societatis Botanicorum Poloniae. 1991; 60(1-2): 127-32.

[27] Bagul M S, H Padh, Harish Rajani, M. A rapid densitometric method for simultaneous quantification of gallic acid and ellagic acid in herbal raw materials using HPTLC. J Sep. 2005; 28(6): 581-4.
[28]Kumar A ,Solanki G S. A rare feeding observation on water lilies (Nymphaea alba) by the capped langur (Trachypithecus pileatus). Folia Phoniatr Legopaed. 2004; 75(3): 157-9. [29] Cudalbeanu M, Ghinea I O, Furdui B, Dah-Nouvlessounon D, Raclea R, Costache T, Cucolea I E, Urlan F, Dinica R M. Exploring New Antioxidant and Mineral Compounds from Nymphaea alba Wild-Grown in Danube Delta Biosphere. Molecules. 2018; 23(6).

[30]Bakr R O, Wasfi R, Swilam N ,Sallam I E. Characterization of the bioactive constituents of Nymphaea alba rhizomes and evaluation of anti-biofilm as well as antioxidant and cytotoxic properties. J Med Plant Res. 2016; 10(26): 390-401.

[31]Bose A, Ray S D ,Sahoo M. Evaluation of analgesic and antioxidant potential of ethanolic extract of Nymphaea alba rhizome. Oxid Antioxid Med Sci. 2012; 1(3): 217-23.

[32]Rehman S, Ashfaq U A, Ijaz B, Riazuddin S. Anti-hepatitis C virus activity and synergistic effect of Nymphaea alba extracts and bioactive constituents in liver infected cells. Microb Pathog. 2018; 121: 198-209.

[33] Paharia A, Pandurangan A. Evaluation of hepatoprotective activity of ethanolic extract of Nymphaea alba 
Linn flower in experimental rats. Int $\mathbf{J}$ Biomed Res. 2013; 4(7): 349-54.

[34] Bakr RO E-N M, Zaghloul SS, Omar MM. Profile of bioactive compounds in Nymphaea alba L. leaves growing in Egypt: hepatoprotective, antioxidant and anti-inflammatory activity. BMC Complement Altern Med. 2017; 17(1):52.

[35] Mohammad Nasiruddin I A K, S H Arif. Protective Effect of Nymphaea alba Linn Flowers Against Isoniazid Induced Toxicity in Experimental Rats. Int J Pharm Pharm Sci. 2017; 5(5).

[36] Ghazi Malih Al-Maliki K K A-K a R M K. Antibacterial activity of two water plants Nymphaea alba and Salvinia natans leaves against pathogenic bacteria. Int $\mathrm{J}$ Fish Aquat Stud. 2017; 5(5): 353-5.

[37]Koushik O S, Himaja V, Babu P S ,Karthikeyan R. Invitro Anti-Bacterial Activity Of Flowers of Nymphaea alba. Ind J Drugs. 2015;3(2):47-8.

[38]Bonjar S. Evaluation of antibacterial properties of some medicinal plants used in Iran. J Ethnopharmacol. 2004; 94(2-3): 301-5.

[39] Arzu Birinci Yildirim F P, Karakas, Arzu Ucar, Turker. In vitro antibacterial and antitumor activities of some medicinal plant extracts, growing in Turkey. Asian Pac J Trop Med. 2013; 6(8): 616-24.
[40]Batool R K A, Akbar I, Arshad N, Jamil N. Antilisterial Effect of Rosa damascena and Nymphaea alba in Mus musculus. Biomed Res Int. 2018; 2018: 9.

[41]Eerike M. Antidepressant activity of Ethanolic extract of Nymphaea alba flower in albino mice. Int $\mathrm{J}$ Pharma Bio Sci. 2013; 4(4): 353 - 7.

[42] Shankar A S k r, Raghuprasada M. S., Ramachandra K., Keerthi Sagar , Reshma S. R. Evaluation of anticonvulsant activity of ethanolic extract of Nymphaea alba Linn. (white water lily) and its comparison with phenytoin sodium and sodium valproate in albino rats. JPR:BioMedRx: Int J. 2013; 1: 135-9.

[43]Raju N J, Vani B S, Santhi G, Lavanya L ,Vishala $\mathrm{T}$ C. Evaluation of antihyperlipidemic activity of Nymphaea alba. Int $\mathrm{J}$ Pharm Sci. 2016;7(8):3432.

[44] Madhusudhanan N, Lakshmi T, Kumar G, Ramakrishanan K V, Roy A, Geetha R. In vitro antioxidant and free radical scavenging activity of aqueous and ethanolic flower extract of Nymphaea alba. Int J Drug Dev Res. 2011; 3(3): 252-8.

[45]Javadi E M F, Karbassi A. R., Monavari S. M. Removal of lead, cadmium and manganese from liquid solution using water lily (Nymphaea 
alba). J FOOD AGRIC ENVIRON. 2010; 8(3): 1220-5.

[46] Khurshid S, Kausar S, Afzal S, Adnan A, Mehmood A, Arshad M ,Bukhari Z A. Adsorption study of Nymphaea alba for the removal of manganese from industrial waste water. INT J PHYS SCI. 2013; 8(45): 2052-62.

[47]Zhu M, Zheng X, Shu Q, Li H, Zhong P, Zhang H, Xu Y, Wang L, Wang L. Relationship between the composition of flavonoids and flower colors variation in tropical water lily (Nymphaea) cultivars. PloS one. 2012; 7(4).

[48] Klink A. Content of selected chemicals in two protected macrophytes: Nymphaea alba (L.) and Nuphar lutea (L.) SIBITH \& SM. in relation to site chemistry. POL J ECOL. 2004; 52(2): 229-32.

[49]Kok C, Meesters H ,Kempers A. Decomposition rate, chemical composition and nutrient recycling of Nymphaea alba L. floating leaf blade detritus as influenced by $\mathrm{pH}$, alkalinity and aluminium in laboratory experiments. Aquat Bot. 1990; 37(3): 215-27. 